Article

\title{
Preliminary Practices: Bloody Knees, Calloused Palms, and the Transformative Nature of Women's Labor
}

\author{
Kati Fitzgerald \\ Department of Comparative Studies, The Ohio State University, Columbus, OH 43210, USA; \\ fitzgerald.268@osu.edu
}

Received: 24 September 2020; Accepted: 23 November 2020; Published: 26 November 2020

\begin{abstract}
In this article, I explore the prostration accumulation portion of the Preliminary Practices of a specific group of Tibetan Buddhist women in Bongwa Mayma, a rural area of Yushu Tibetan Autonomous Prefecture in Qinghai Province. I focus specifically on the nuns and lay women who utilize this set of teachings and practices. The Preliminary Practices not only initiate practitioners into a specific tradition (that of the Drikung Kagyu and more specifically the Amitabha practices of this lineage), but also more fundamentally into Vajrayāna Buddhism as it is practiced in contemporary Tibet. Although monks and male lay practitioners in this region also tend to perform the same Preliminary Practices, I focus specifically on women because of their unique relationship with bodily labor. I begin this article with a discussion of the domestic and economic labor practices of contemporary Tibetan women in rural Yushu, followed by an analysis of Preliminary Practices as understood through the Preliminary Practice text and oral commentaries utilized by all interviewees and interviews (collected from 2016-2020) with female practitioners about their motivations, experiences, and realizations during the Refuge and prostration accumulation portion of their Preliminary Practices. Women themselves view bodily labor as a productive and inevitable aspect of life. On the one hand, women state openly that their domestic duties impede upon their ability to achieve religious realization. On the other, they frequently extol the virtues of hard work, perseverance, patience, and fortitude that their lives of labor helped them to cultivate. Prostration is meant to embody the act of going for Refuge, of submitting oneself to the teachings of the Buddha, to the path of the dharma, and to the community of religious practitioners with whom they will study and grow. Prostrations are meant to embody the extreme difficulty of Refuge, to remove obscurations, to crush the ego, and to confirm a dedication to endure the hardships on the path to realization. Buddhist women, despite their ambiguous relationship with physical labor, see the physical pain of this process as a transformative experience that allows them a glimpse of the spaciousness of mind and freedom from attachment-filled desire promised in the teachings they receive.
\end{abstract}

Keywords: religious labor; Buddhism; Tibetan Buddhism; Drikung Kagyu; Yushu Tibetan Autonomous Prefecture; Qinghai; women; nuns; lay women; Preliminary Practices; prostrations; Amitabha

\section{Introduction}

Trinley Sangmo laughs and grimaces simultaneously as she recalls her own Preliminary Practices. She shows me on her body where she developed wounds during her prostrations: her palms, her knees, her forehead. She closes her eyes tightly and recites mantras breathily in the countenance she adopts whenever she discusses Lama Tenzin Nyima Rinpoche. She talks about the wear and tear her body experienced while accumulating her 100,000 prostrations - of the aching joints and bloody bandages 
that tore her wounds open when she changed them. She speaks of this time with a combination of pride and reverence. It was difficult; she completed it; she was changed by it.

In this article, I explore the Preliminary Practices (sngon 'gro) of a group of women in a Tibetan region of Qinghai Province called Bongwa Mayma ('brong pa smad ma; pronounced in the local dialect as Bongwa Mayma), focusing specifically on the nuns and lay women who utilize a set of teachings and practices originally composed by the 4th Lho Bongtrul, Orgyan Nuden Dorje (1849-1902; lho 'brong sprul o rgyan nus ldan rdo rje; henceforth Nuden Dorje). These Preliminary Practices have been compiled and edited by the current Lho Bongtrul Tenzin Nyima Rinpoche ${ }^{1}$ (henceforth referred to as Lama Tenzin Nyima) ${ }^{2}$. These practices and teachings not only initiate practitioners into the Drikung Kagyu tradition of Tibetan Buddhism, and more specifically the Amitabha practices of this lineage, but also more fundamentally, into Vajrayāna Buddhism as it is practiced in contemporary Kham. Although monks and male lay practitioners in this region also tend to perform the same Preliminary Practices, I focus specifically on women because of their unique relationship with physical labor ${ }^{3}$. This unique relationship with labor, I argue, is central to understanding how women conceptualize their religious progress during the Preliminary Practices.

In Buddhist contexts, women's relationship with physical labor is deeply embedded in their physical form as women. Although it is quite well established scripturally that a female must first transform into a male in order to achieve enlightenment (Balkwill 2018), what interests the women in this study was not necessarily the final step from highly realized being to fully enlightened Buddha. Women tend to have shorter-term goals and are more invested in how their female body participates in the processes of realization prior to enlightenment, in this very lifetime. The formation of a female body in a Buddhist context is complex-from one perspective, the body is a manifestation and place holder for a consciousness that will accumulate karmic imprints, a lens through which the faculties (dbang po) receive and process information and make assessments about sensory inputs. The body is a precious and necessary element for realization, one that should be kept clean and healthy, should be honored but not indulged. The body can also be a distraction to the Buddhist mind-a source of desires, hungers, pain, sickness, and decay that detract from the ability of the practitioner to achieve realization. In Buddhism, forms are empty, but despite that philosophical truth, the female form is still messier. This is partially due to the misogynistic conditions of the world-a condition that existed during the time of the Buddha and persists in one way or another to this day. But this is also due to those aspects of female life that differentiate them from men: birth (Langenberg 2017), menstruation, menopause, and being the object of lust and desire for men.

Of course, in the context of an academic environment in which gender and sex are conceived of as performative functions of social life, as opposed to biological categories, thinking of women as marked physical entities (beings with vaginas, who are able to procreate) is essentialist and hetero-normative. In opposition to the academic view of a performative spectrum of gender, Tibetan Buddhists in Qinghai have a more physiological, binarial understanding of gender. I believe it is important to recognize the

1 The 7th incarnation of the Lho Bongtrul manifested as four different individuals. The body emanation was Nyandrak Namgyal (lho rje drung dkon mchog lhun grub snyan grags rnam rgyal dpal bsang po) (b. 1976), who later moved to America and gave up the title. The speech emanation is Dongag Tenzin Rinpoche (dkon mchog mdo sngags bstan 'dzin) (b. 1979), who lives in Xining with his wife and children. The heart emanation is Lama Tenzin Nyima Rinpoche (lho bstan 'dzin nyi ma) (b. 1965), who remains in residence at Lungkar Monastery in Yushu, and finally, the knowledge emanation (yon tan gyi sprul pa-sometimes referred to as the quality emanation) Karma Ratna Trulku (o rgyan rang byung 'gro 'dul bde chen rdo rje) (b. 1980) was recognized in 1999 and lives in his father Ongtrul Rinpoche's monastery in Tso Pema, Himachal Pradesh with his wife and children.

2 zab chos bde chen zhing sgrub kyi sngon 'gro'i khrid yig lam mchog padma'i thems skas [Instructional Text for the Preliminary Practices of the Profound Teachings of Amitabha's Pureland Sadhana: Steps on the Supreme Lotus Path] (lho rje drung nus ldan rdo rje 2008).

3 There is a long and rich history of feminist class analysis, which calls attention to the relationship between gender and labor, especially unquantified women's domestic and emotional labor in the home (cf. Benston 1969), as well as questioning the viability or productivity of using class categories as a liberative tool (cf. Vogel 1995). Within the field of Buddhist Studies, Kim Gutschow's work on Zanskari nuns performs a class analysis to the economic labor relations of nunneries (Gutschow 2001, 2004). 
impact of third and fourth wave feminist theory on the field of gender studies and not to return to a biological deterministic view of gender simply to match the rhetoric of my interlocuters. By this I mean that I myself am influenced by an anti-essentialist understanding of gender and sex (Grosz 1995; Fuss 1989) and am deeply aware of the ways in which intersectionality of race (Hooks 1981), ethnicity, citizenship (Simpson 2014), gender, sexuality, and class (Hooks 2000) all work in complex ways to form identity. At the same time, it would be inaccurate to say that women in this area are concerned with or thinking deeply about how their sex is socially constructed. For the women of Bongwa Mayma, a woman is a woman because of her body. She has genitals and the capacity to bleed and give birth, which marks her as simultaneously less pure and more of a sexual distraction than her male counterparts ${ }^{4}$. We might read this as a kind of strategic essentialism (Spivak 1993; Grosss 1985), but these are not the terms in which women themselves frame their concerns.

The ideas of suffering, liberation, and realization that women expressed to me were deeply interwoven into their ideas of body. They suffer because they are objects of lust, because they are weaker physically, because they menstruate, because they have to give birth, because they breastfeed, because they are restricted from certain religious practices and spaces. They view their sex as immutable in this lifetime, a feature of their birth which is unchangeable and undesirable. I argue that these material conditions of sex and gender produce a direct and tangible relationship with labor for Tibetan Buddhist women. Women perform more physically exhausting and all-consuming labor than their male counterparts and this colors their ways of understanding the Preliminary Practice of prostration.

Because of this unique relationship with labor, I begin this article with a brief discussion of the labor practices of contemporary Tibetan women in this region. This is followed by an analysis of Preliminary Practices as understood through two main sources: (1) the Preliminary Practice text and oral commentary utilized by all interviewees (lho rje drung nus ldan rdo rje 2008) ${ }^{5}$, and (2) interviews with female practitioners about their motivations, experiences, and realizations during the Refuge and prostration accumulation portion of their Preliminary Practices ${ }^{6}$.

\section{Domestic Labor, Childcare, and the Nomadic Woman}

Within the field of Tibetan Studies, there has been a recent uptick in interest in women's religion. Following a call by Barbara Aziz for more data on Tibetan women's lives (Aziz 1987, 1988), a growing number of biographical translations (Schaeffer 2004; Diemberger 2007; Adhe 1997; Jacoby 2014; Gayley 2017; Namgyal Lhamo Taklha 2004; Henrion-Dourcy 2005; Gyatso and Havnevik 2005; Havnevik 1999; Allione 1984; Bessenger 2017), studies on nunneries (Gutschow 2001, 2004; Havnevik 1990), and historical searches for traces of women in ancient Tibetan literature (Martin 2005; Tsomo 1988;

4 For more on the contrary roles of Buddhist women as representatives of the pure mother or the object of lust, see (Keyes 1984). For more on sexuality in the Buddhist world, see (Cabezon 1992; Faure 1998, 2003; Paul 1989).

5 During the summer of 2019, nuns at Dzalung Nunnery also received instructions from a guest Khenmo on Dza Patrul's Preliminary Practice text (rdza dpal sprul 19th century). In December 2019, Lama Tenzin Nyima gave seven days of oral instructions on a new Preliminary Practice text for the lay and monastic community. This text is a Fivefold Mahamudra Preliminary Practice text (lho bstan 'dzin nyi ma 2019a) in the Drikung Kagyu tradition. During oral instructions and practice sessions (lho bstan 'dzin nyi ma 2019b), he relied heavily on the commentary he had written in the Amitabha Preliminary Practice text referred to in this article, as well as collected songs of Milarepa relevant to the specific practices. Recordings from the oral instructions on the Amitabha Pureland Preliminary Practices closely resemble the printed commentary and the teachings given in December 2019 (attended and recorded by the author) compliment and support those instructions (lho bstan 'dzin nyi ma 2008).

6 These interviews were conducted from December 2016 to February 2020, during which time I lived and worked alongside women in Lho Lungkar Monastery and Dzalung Nunnery (December 2016-January 2017, July 2017-July 2018, and October 2019-February 2020) and with members of the Bongwa Mayma diaspora in Bodhgaya (September-November 2018), Kathmandu (December 2018), Himachal Pradesh (January-April 2019), and Dehradun (May 2019). The majority of the material for this paper was gathered while living full-time in Lho Lungkar Monastery and working in the monastic kitchens of Lho Lungkar and Birru Monasteries, attending prayer festivals, assisting in Lho Lungkar Monastery medical clinic, and visiting families (for periods of time ranging from a few hours to a few weeks) connected with the religious life of the region. 
Shaw 1995) continue to appear in print ${ }^{7}$. In the field of Buddhist Studies, sustained attention has been paid to questions of ordination for Buddhist nuns (Bianchi 2019; Heirman 2001, 2011), representation of female goddesses (Shaw 1995), and historical and scriptural indications of the place of Buddhist women within the sangha (Blackstone 1998; Law 1927; Horner 1930; Balkwill 2018). Despite these resources, long-term ethnographic studies on Buddhist women have been much rarer. The work of pioneering anthropologists like Charlene Makley (Makley 2007, 1997, 2002, 1999) and the more recent work of early career ethnographers like Elizabeth McDougal (McDougal 2016), Anne Kukuczka (Kukuczka 2016), etc. are producing ethnographic studies of Tibetan women's everyday lives, while others work to describe the religious lives of Buddhist women outside Tibet (Arai 2011). My own work in Bongwa Mayma seeks to create a more nuanced picture of women's religious lives by thinking not only about the religious texts they use or their formal biographies, but also about their daily relationship with their laboring bodies.

Bongwa Mayma is a nomadic area in Yushu Tibetan Autonomous Region, located on the border between Nangchen and Dzadö Counties in Qinghai Province (nang chen dang rdza stod rdzong). The main forms of economic production in the region are a combination of nomadic animal husbandry and caterpillar fungus (dbyar rtswa dgun 'bu) ${ }^{8}$ cultivation. Nomadic household duties are almost exclusively performed by women, while men take responsibility for the economic duties outside the home (buying and selling livestock and materials, transportation, political and economic negotiation, etc.).

After eight days of funerary ceremonies at Lungkar Monastery for Gyalpo Rinpoche, 67-year-old Nyangtsang matriarch Tsepa and her husband Gyatsey asked me to give them a ride home to their nomadic settlement. Tsepa is a tiny woman, stocky in stature and never seen without her head dressing (spos shel), a heavy crown of amber, coral, turquoise, and bone gems sown onto cloth straps that drape far down her back. She is quick to smile and loves a bit of gossip, but her fingers are bent into odd angles from arthritis and prolonged overuse. The camp consists of four households, three of which are related by blood. After arriving at dusk, I spent the night in their settlement and when I got up the following morning:

The two-day-old full moon is still out over the mountains, and the four women currently at home (Choekar, Tsepa, Kunchok Palmo, and Lhamo Yangdzom) are out collecting yak dung before releasing the yaks to graze for the day. I squat to pee overlooking the fields, where a soft fog is rising off the frozen dew, and go to wash up at Tsepa's house, where Lhagyal (Tsepa's son) and Gyetsey are still sleeping with the youngest children. Kunchok Palmo, Tsepa's daughter and a Dzalung Nunnery (rdza lung dge dgon) nun, is wrangling the stove back to life and tells me there is no hot water yet to wash, so we use cold water to brush our teeth and wash our face. A teenage girl Taryang and I take the buckets and yokes down to the stream at the bottom of the valley to collect water for the day. Kunchok Palmo brews tea on the now roaring fire and the men come out of their rooms to ensure the herds are set on course to their proper pastures and then receive breakfast ${ }^{9}$. Over a breakfast of milk tea and tsampa (roasted barley ground into a flour and eaten as a kind of oatmeal mixed with dried cheese, butter, and tea), the family discusses plans for the day. Everyone is finishing up their morning prayers as they bustle about, washing up, eating, dressing, and preparing for their work. Kunchok Palmo's prayers are interrupted as she refills tea and washes dishes, and Tsepa puts down her hand-mani (ma

7 See (Melnick 2020) for an overview of the current state of the field.

8 For more on the practice of caterpillar fungus collection across the Tibetan Plateau, see (Winkler 2009; Boesi 2003).

9 Since government initiatives began enforcing fencing on the pastures, itself a controversial policy, herding duties for nomadic men have decreased considerably. Fencing initiatives were officially implemented during the Sipeitao Jianshe [Four Constructions Initiative] between 1996-2004, but nomads did not identify this campaign or a specific date in time for the introduction of fencing (for more on the Four Construction policy, see Gruschke 2008, p. 6). Because of the boundaries, they no longer have to accompany the herds all day-they can be released into one pasture in the morning and fetched before sunset. This leaves the middle of the day free for leisure activities, but also means that most families have abandoned the mid-day milking. Although I did not encounter any truly negative opinions of the fencing by current herders, the older generation still expressed a dislike of the interference in their traditional ways of herding and a sense that nothing good could come from more government involvement in their life and pastures. 
ni lag skor) to comb the children's hair. She is rough getting out the knots, occasionally using the butt of the comb to smack the wiggling and whining children into compliance, all the while continuing to recite her prayers. Kunchok Palmo continuously has to stop recitations to get up and stoke the fire, replenish water, feed others, and go get dung.

So much happens in a nomadic home before the sun fully rises and the day's work continues throughout all waking hours as family members tend to animals, clean and mend the house and stables, cook five meals, care for children, and transform raw animal products into items that can be consumed or sold. These responsibilities and daily activities shape the ways in which women talk and think about their religious practice.

Women's labor not only encompasses the realm of domestic labor, but spreads to the duties of child labor, including childbirth, rearing, education, discipline, and nurturing.

Aney is 64 years old and has given birth eleven times. Four of her children, two boys and two girls, have died. She also adopted an infant after its mother died in childbirth, leaving her with seven biological children and one adoptive child. She tells me about the loss of her twin boys a number of times during our time together. She repeats this story when we discuss my own fertility (a favorite subject among my female friends), as well as when she recounts her oral history to me. Alone in her home, her husband away for work, she went into labor and delivered two twin boys herself. She cut their umbilical cords herself, wrapped them in a blanket, and went outside to tend to the herds. If she didn't bring home the animals and milk them, they could die or get ill and then the whole family would starve. She was hemorrhaging blood and the twin boys were weak and sickly. She tried to nurse them and tend the herds, but before her husband could return home, the children died. She went to a hospital and received an injection to stop her own bleeding, but there was nothing to be done for the babies (a ne 2018).

Over the course of nearly three years of fieldwork and interviews, every woman I interviewed over the age of 35 had lost at least one child. Reasons for the high child mortality rate amongst these women have various causes, including higher rates of pregnancy complications, including hypoxia in high-altitude populations and pre-eclampsia due to the high-fat diet of nomads (cf. Craig 2009). Nomadic populations also lack access to hospitals, sometimes living more than a day's journey away from any medical center. The climate and environment play an important part in child mortality. This region has habitable camps at elevations over $4500 \mathrm{~m}$, which is well above the tree line, and temperatures can reach as low as -40 degrees Celsius with high winds. Although not much bacteria can survive in such a cold and dry environment, water sources are often also used as lavatories and the drinking water is untreated and unfiltered, resulting in at least some contamination. Children face environmental dangers, such as extreme weather, and dangers associated with living in a high-altitude, nomadic environment. At least one child drowned in a river during my fieldwork period. Whatever the myriad causes, it is a reality of life for this population that motherhood comes with the burden of seemingly inevitable child mortality.

In addition to the obvious difficulties of pregnancy and labor, along with the treacherous emotional processes involved in child loss, women's child-rearing duties do not end with birth.

Pasang got pregnant with her fifth child at 40 years old. Her next oldest son was 12 years old at the time, and she remembers having to stop him from breast feeding after she became pregnant again. Although he obviously ate solid food and no longer relied upon breast milk for nutrition, he still suckled for comfort at night or when he was upset. After becoming pregnant unexpectedly, she had to stop him from breastfeeding so that the fetus would not be deprived of the nutrients going to her breast milk (pa sangs 2018).

Pasang's experience is not unique in that most mothers stop breastfeeding one child when they become pregnant with another due to the enormous strain that breast-feeding and pregnancy put on a 
woman's body. Child rearing duties do not end after menopause either, as most grandparents live with one of their sons and his new bride and continue to care for young children until they are too sick to contribute. Young children often cleave to their grandparents, and frequently sleep with and are more attached to their grandfather or grandmother than their own parents. Mothers and grandmothers can frequently be seen carrying their smallest children tied to their backs or strapped to their fronts when they carry baskets or water on their backs. Children in this region are now required to enter school between eight and nine years old, but traditionally children stay close to their mothers, sharing every aspect of life, until the child enters a monastery or marries into another household. For male children, they will ideally find a bride to enter the home and never leave their parents. For Pasang, for example, her journey as a mother and wife began at 19 years old, and she continues to breastfeed and care for an infant 22 years later. When her son decides to marry, she will again take on the responsibility of caring for her grandchildren.

\section{The Preliminary Practices as Religious Labor}

Despite the strain of domestic and child labor upon Bongwa Mayma's women, their first entry-point into serious religious practice is also physical labor. Although there is a large diversity across Tibetan Buddhist traditions on the timing, order and pace of the Preliminary Practices, we can generalize by saying that novices in the Nyingma (and Dzogchen), Sakya, and Kagyu schools of Tibetan Buddhism utilize Preliminary Practices as a way of initiating new members of the sangha, preparing practitioners for Tantric initiation, and introducing the fundamental practices of the lineages. Although the term "preliminary" (sngon du 'gro ba) might indicate that these practices are done prior to a more important or more profound set of teachings, lamas emphasize again and again that the preliminary teachings are the teachings and that they are not meant to be a primer for something separate. Rather, they are the foundational practices, which will be used in various combinations throughout all future practice.

The particular Preliminary Practice text that members of the Lungkar Monastery nexus currently use is an Amitabha Pureland (zhing sgrub) text, which is comprised of a number of Treasure texts (gter ma) revealed or composed by Nuden Dorje in the 19th century and compiled into a Preliminary Practice text and explained in a detailed commentary by Lama Tenzin Nyima in $2008^{10}$. The Preliminary Practices are divided into the General Outer Preliminaries (thun mong phyi'i sngon 'gro) and Extraordinary Inner Preliminaries (thun min nang gi sngon' gro), each of which have their own divisions. The Outer Preliminaries involve study and contemplation on the Four Thoughts that Turn the Mind (what we might call the Four Motivations to Practice) (blo ldog rnam bzhi). These Four Thoughts are explained in detail in the root and instructional text following the sadhana, as well as in Lama Tenzin Nyima's audio recordings of the instructions. The Four Thoughts are:

(1) the difficulty of obtaining the freedoms and favorable conditions ${ }^{11}$ (i.e., a human birth) (dal 'byor rnyed par dka' ba) (lho rje drung nus ldan rdo rje 2008, pp. 49-59)

(2) the inevitability of impermanence and death ('chi ba mi rtag pa) (lho rje drung nus ldan rdo rje 2008, pp. 59-67)

10 It should be noted that although this particular Preliminary Practice text and commentary is original, it is not unique in its structure, philosophy, or practice. It follows in a long lineage of Preliminary Practice commentary texts, a genre most popularly represented by Dza Patrul Rinpoche's Words of My Perfect Teacher (kun bzang bla ma'i zhal lung) (rdza dpal sprul 19th century).

11 The Eight Freedoms are having the advantage of not having been (1) born in the hell realms, (2) born as a hungry ghost, (3) born as an animal, (4) born with no access to the dharma, (5) born as a demi-god, (6) born with a revulsion for the dharma, (7) born with no access to the teachings, and (8) born with a mental or physical disability. The Ten Favorable Conditions are broken into two sections: the Personal Favorable Conditions (rang 'byor lnga) and the External Favorable Conditions (gzhan 'byor lnga). The Ten Favorable Conditions are (1) being born as a human; (2) living where there is dharma; (3) being able to hear, see, and think; (4) having met no obstacles to coming into contact with the dharma and your teacher; (5) having confidence in the dharma and faith in the teacher; (6) the existence of a Buddha in this kalpa; (7) that this Buddha taught the dharma; (8) that the teachings still survive; (9) having dharma friends; and (10) having patrons (lho rje drung nus ldan rdo rje 2008, pp. 50-53). 
(3) workings of cause and effect (las rgyu 'bras) (lho rje drung nus ldan rdo rje 2008, pp. 67-86)

(4) the disadvantages of the samsāric world ('khor ba'i nyes dmigs) (lho rje drung nus ldan rdo rje 2008, pp. 86-118).

Contemplation on these ideas should inspire the practitioner to take advantage of their precious (but brief) human life, not waste any time, understand the consequences (and power) of their own actions and turn away from the samsāric world toward a life of practice. The practice of contemplating the Four Thoughts can take various forms. For monastics completing the Preliminary Practice during a sealed retreat, the first period of retreat would include a silent period of contemplation on the Four Thoughts that could last between eight days (two days per thought) and one month (one week per thought). After this initial period of contemplation and study, the practitioner receives permission and embarks upon the Inner Preliminary practices, which involve:

(1) taking refuge (skyabs su 'gro ba) (lho rje drung nus ldan rdo rje 2008, pp. 119-41),

(2) generating bodhicitta (byang chub sems bskyed) (lho rje drung nus ldan rdo rje 2008, pp. 141-53),

(3) reciting the mantra and performing the meditations of Vajrasattva ( $r$ do sems sgom bzlas) (lho rje drung nus ldan rdo rje 2008, pp. 153-69),

(4) making mandala offerings (tshogs bsags mandala) (lho rje drung nus ldan rdo rje 2008, pp. 169-84), and

(5) performing Guru Yoga (bla ma'i rnam 'byor) (lho rje drung nus ldan rdo rje 2008, pp. 185-203).

I focus in this article on the first of the Inner Preliminaries: the process of taking refuge in the three jewels. This process involves recitation of a specific verse while performing full-body prostrations. The verse prescribed in this particular teaching is:

sku gsum rtsa brgyud bla ma yi dam tha / sangs rgyas chos dang 'phags pa'i dge 'dun tshogs / dpa' bo mkha' 'gro dam can chos srung la / bdag gzhan byang chub bar du skyab su mchi

I take refuge until myself and others have accomplished enlightenment in the three kayas ${ }^{12}$ of the root and lineage gurus, the tutelary deity, the Buddha, Dharma, and the noble Sangha, the ḍākas, dākinīs, and samaya-bound Dharma protectors (lho rje drung nus ldan rdo rje 2008, pp. 8-9).

The process of prostration, accompanying visualizations and recitation of the verse above is repeated 100,000 times. In the following sections, I give a detailed description of the process of prostration and what that practice looks like and means in the lives of Bongwa Mayma's women.

\section{Prostrations: Submission of the Body}

What does a prostration entail? A prostration is the movement of the body from a fully erect position to laying completely prone upon the ground and a return to the standing position. This movement is accompanied by hand motions that place the fingertips together with the thumbs resting in the space between the palms. The hands move up to the crown of the head, down to the throat, down to the heart and then open, palms facing forward as the body moves down to the floor. When down on the ground, the arms go straight above the head, palms flat on the ground, and then move up to the crown of the head with the fingertips pressed together. After rising once again to a standing position, the hands return to the heart-center before beginning the process again. This physical act is performed while reciting the Refuge Prayer quoted above and visualizing the Field of Accumulation (tshogs zhing; See Figure 1) in Amitabha Buddha's Pureland (bde ba can) (lho rje drung nus ldan rdo rje 2008, pp. 128-33).

12 Dharmakaya (chos sku), Sambhogakaya (longs spyod rdzogs pa'i sku), and Nirmanakaya (sprul pa'i sku). 


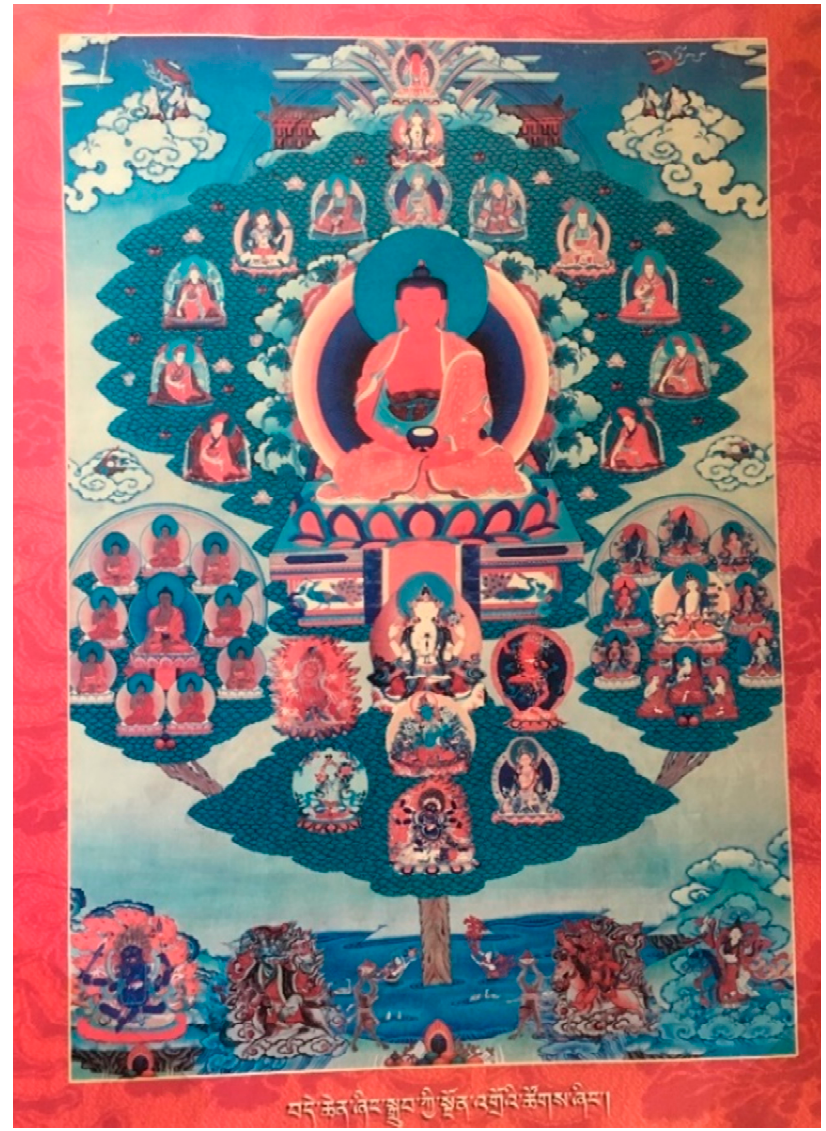

Figure 1. Meditational guide of Amitabha's Field of Accumulation produced by Lho Lungkar Monastery.

Lama Tenzin Nyima describes the act of going for Refuge as the primary performance that moves a novice from the stage of being a non-Buddhist to a Buddhist, emphasizing the fact that skill or knowledge does not determine one's status as Buddhist, but rather one's Refuge does (lho rje drung nus ldan rdo rje 2008, pp. 119-20). The quality and strength of one's Refuge depends on the degree of one's faith and devotion (lho rje drung nus ldan rdo rje 2008, pp. 120-22). The object of Refuge is the Three Jewels, the Buddha, Dharma, and Sangha. The process of prostration is described by Lama Tenzin Nyima Rinpoche as follows: maintaining the meditation on all the objects within the Field of Accumulation (pictured above), imagine that you are surrounded by your relatives, friends, enemies, and all sentient beings who are also performing the same Refuge and prostrations. As your hands come to the crown of your head, take refuge in the body of the object of refuge and visualize that all iniquities of the body are cleansed. As your hands come to your throat, take refuge in the speech of the refuge object and all iniquities of speech are cleansed. Finally, as your hands come to your heart-center, take refuge in the mind of the refuge object and all iniquities of thought are purified. As the five points of the body come into contact with the ground, imagine that the kleshas (disturbing emotions) and five poisons ('dod chags, zhe sdang, gti mugs rgyal, phrag dog) are cleansed (lho rje drung nus ldan rdo rje 2008, pp. 134-37). This process of verbal recitation, mental meditation, and physical labor is repeated 100,000 times (see Figure 2). 


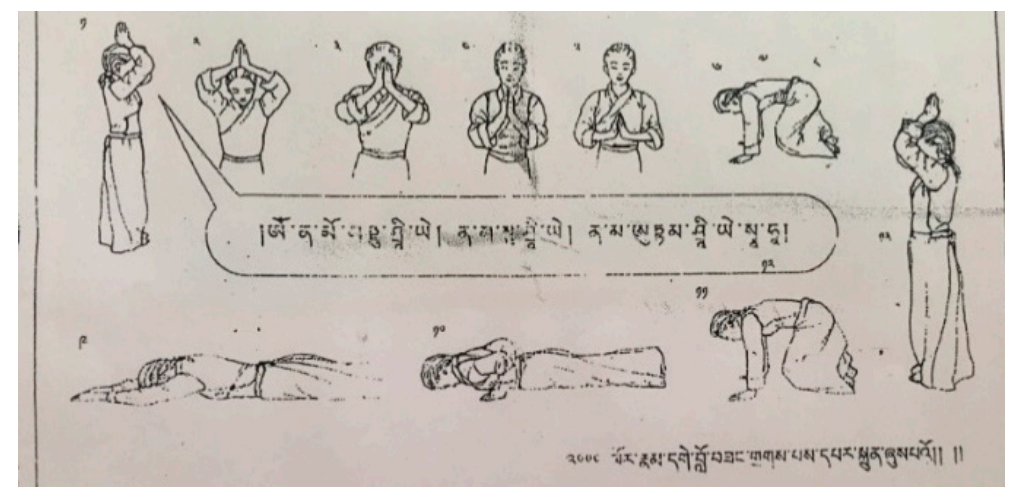

Figure 2. A handout given to prostrating practitioners at Bodhgaya's Mahabodhi Temple grounds, produced in 2000 by Namgey Lobsang Trapa.

How do women themselves understand the act of taking Refuge through a process of extreme physical labor? In order to understand women's own point of view, formal interviews were not the most fruitful avenue. Discussions with women who had completed their own Preliminary Practices increased in volume considerably as I began the process of accumulating my own prostrations. The transition from an intellectual understanding of the difficulty of prostration to a physical, visceral one, resulted in new opportunities for women not only to share their experiences, but also their advice.

45-year-old mother of six, Kundrol, tells me how she accumulated 3000 prostrations every day during her Preliminary Practice. I tell her how I can barely manage 500 each day in between my cooking duties at the monastery. She downplays her own abilities by telling me of certain monks or young men who can accumulate up to 5000 in one day. When I point out the fact that she continued to care for a family of eight during this process, she laughs. I ask her about the effects on her body and she says it was very painful to walk, sleep, crouch to use the toilet, or bend to pick anything up during that time, but she mentions that she is used to hard work, not unaccustomed to aching joints and sleepless nights. She tells me however many prostrations I can do is good and to just keep going.

Kunchok Choedron is a 56-year-old nun, but stays at home with her aging parents approximately half of the year. She performed her Preliminary Practices in the nunnery while in retreat. Her young cousin stayed with her to cook, clean, fetch water, keep the stove lit, and make tea. She points to the parts of her body that caused her problems during the practice-her back, her knees, her shoulders. She mentions that she performs dozens of fasting rituals (smyung gnas) each year, so she knows that discomfort is best dealt with gradually - you get used to anything you do enough of. Prostrations are more mental than physical, so she suggests anytime you feel exhausted to rest in the beautiful emptiness of mind that comes from exhaustion. But don't rest too long-sit for one minute after every prayer bead cycle (108 prostrations) and break apart the sessions.

Many of the women took time away from their household or monastic duties during their Preliminary Practices, but others had to squeeze in domestic and childcare duties around their busy schedule. Women presented the following as one ideal schedule while performing this first step of the Preliminary Practices:

Most practitioners follow some version of the above schedule (see Table 1): four daily practice sessions broken apart around the three larger meals (breakfast, lunch, dinner), and interspersed with the two secondary meals (mid-morning and mid-afternoon snacks) and various tea breaks. Both lay women and nuns emphasized again and again that it is very important to eat enough food and to sleep well, but it is also important not to rest too much. If your muscles get cold and stiff, it will be even more difficult to get going again. According to Kunchok Choedron, the best method is to maintain a slow, but steady pace throughout all waking hours. In the beginning days, when the body is still adjusting to this new level of exercise, maintain the same schedule, but move more slowly. In a two-hour 
session, for example, you might begin by aiming for only two hundred prostrations (one hundred per hour), but you can work yourself up to six hundred (one hundred per twenty minutes). Do not focus too heavily on the number of prostrations, but rather on maintaining the quality of your meditation and intention. But also do not stop-even when the meditation falters or the mind wanders, keep moving, keep pushing forward. This message was consistent throughout all the advice I received: Transformation on the Buddhist path is not soft and pleasant, but neither is a woman's life, so just keep going.

Table 1. Daily schedule of prostrations.

\begin{tabular}{|l|l|l|l|}
\hline Morning & \multicolumn{3}{|l|}{ Afternoon } \\
\hline Time & Activity & Time & Activity \\
\hline 3:30 a.m. & Wake up, wash, offerings & & \\
\hline 4-6 a.m. & Open session 1, Prostrations & $3-5$ p.m. & Open session 3, Prostrations \\
\hline 6-6:15 a.m. & Tea & $5-5: 30$ p.m. & Mid-afternoon meal \\
\hline 6:15-8:15 a.m. & Prostrations, Close session 1 & $5: 30-7: 30$ p.m. & Prostrations, Close session 3 \\
\hline 8:15-9 a.m. & Breakfast & $7: 30-7: 45$ p.m. & Tea \\
\hline 9-11 a.m. & Open session 2, Prostrations & $7: 45-10$ p.m. & Open session 4, Prostrations \\
\hline 11-11:15 a.m. & Mid-morning meal & $10-10: 15$ p.m. & Close session 4 , offerings \\
\hline 11:30-1:30 p.m. & Prostrations, Close session 2 & & \\
\hline 1:30-3 p.m. & Lunch, rest & $10: 15$ p.m. & Dinner, Sleep \\
\hline
\end{tabular}

\section{Transformative Power of Labor: Women's Lives as an Extended Labor Metaphor}

Religious and domestic labor are both forms of work, as in they are systems of action that produce results. Religious and domestic labor are also ways of indicating morality, good behavior, and dedication to parents, deities, or monasteries. Both lay and monastic women perform more labor than their male counterparts, and this unique relationship with physical labor is conceived of in two important ways by the women of Bongwa Mayma: as an obstacle to practice and as an essential element of liberation. In either of these cases, labor does something to women. It either prevents them from having the time, resources, or freedom to participate in religious activities (especially those religious activities that make similar demands on a woman's physical body, time, or resources as their domestic labor) or their domestic labor makes them better practitioners. But in either case, the women understand the labor of religious and domestic realms as transformative. This framework of efficacy both indicates productivity, as well as relies upon labor and effort as a transformative tool.

These two ways of understanding the relationship between labor and religious realization are not mutually exclusive, and the same woman might express both views, even over the course of one conversation. Domestic labor is both a samsāric burden that detracts from spiritual practice, as well as a training for both the aversion to the samsāric world necessary to begin the spiritual journey, as well as the extreme dedication and perseverance necessary to achieve spiritual accomplishments. In the following sections, I provide examples of women's own explanations of the relationship between labor and spiritual realization.

\subsection{Labor as Prohibitive}

One way in which contemporary Tibetan women frame their relationship with labor, especially domestic labor related to the household and childcare, is that it is a distraction and an impediment to practice. This is an argument familiar to both male and female householders throughout Buddhist history; the home and its demands detract from a householder's ability to break away from the samsāric world. As Martin Mills and others have pointed out, this textual model of ideal monastic practice and lesser lay practice is often far from the religious reality in Buddhist communities (Mills 2000). Adding a layer of gendered analysis, I find that female interviewees are much more likely to bring up their domestic duties in relationship to religious practice than their male counterparts. When asking nuns at Dzalung Nunnery about their experiences becoming nuns, for those who made a conscious decision to 
become a renunciant (as opposed to being placed in the nunnery by family members, for example), almost every nun stated that they chose a religious life to avoid the pain and suffering of marriage and its subsequent domestic labor.

\section{December 2017}

Went with Trinley Sangmo to Dzalung Nunnery to deliver some medicine and deity cards (made by Lama Tenzin Nyima and produced by the monastery) to the retreat complex where nine nuns are in the first month of their three-year retreat. We stop at the house of Namdrol. We go through old cassette tapes together, because Namdrol believes they are starting to deteriorate with age. There are two tapes of Lama Tenzin Nyima's music, which we listen to with joy. There is also a tape of Lama Tenzin Nyima's Preliminary Practice teachings, which Trinley Sangmo said he made for her because they were not able to meet often during her preliminaries. She says the teachings were really helpful and enabled her to complete her practices. I ask her to sing some mani melodies. She does, beautifully. Then we sit around and gossip about former nuns who now put on makeup and post pictures with boyfriends on WeChat. We watch videos from the wedding of Namdrol's niece in Nakchu (she married two nephews of Orgyan Dorje Rinpoche). Namdrol recounts how her niece cried when she had to be married. They all agree that becoming a wife is pure suffering. Trinley Sangmo teases me that I should become a nun and I explain that it is very difficult to be a nun in America, with no monastic community, no source of income, and no teacher. They tell me that becoming a nun would limit my mobility and my opportunities to travel and benefit others. They say that what I am doing now is better than becoming a nun.

I quote this entry from my fieldnotes at length to highlight a few things. The first is the point of view of the nuns about marriage, a point of view shared by a lot of lay women as well: marriage is painful. In this region, marriage generally occurs when a young woman leaves home and enters the household of her husband ( $m n a^{\prime} m a$ 'gro $b a$ ). Although some women marry into a household close to their own homes, many women marry into a household a significant distance from their parental home. Women generally have the right to return to their parents' home once per year for a visit or if there is an illness or birth. There are some occasions when a man would leave his family home and enter the family of his wife (mag pa'gro ba), but this practice is looked down upon and men in this situation are viewed as lacking economic power within the home. When women enter a household, they often marry all the brothers of the home at once. This practice developed in order to keep hereditary lands together and prevent multiple brothers from demanding separate plots of land or herds of their own (thereby diminishing the wealth of the family unit). The tradition remains in use today because nomadic life requires a large amount of work and having more than one young man in the home is seen as a great advantage. For example, if one husband remains at the nomadic settlement to tend the herds, another husband can take animal products to sell in a distant region without leaving the home vulnerable. Women tend not to be able to drive or to have any formal education, making them less able to participate in formal economies in town centers ${ }^{13}$, but they are needed in the home to care for the frequently large family of their in-laws, husbands, and children.

As the nuns pointed out to me, for a young woman, marriage means separation from one's own family, as well as introduction into an unfamiliar family (almost all marriages are still arranged, although this practice is changing as more children leave home for high school or college outside the region). In addition, marriage means the beginning of taking the responsibility of a new household, which can include up to four generations and many members. For most women, marriage marks the beginning of a life of labor, and the Dzalung Nunnery nuns are grateful to be excused from that life of labor. Nevertheless, the nuns' aversion to marriage was not just a foil for praising their own

13 There is a great diversity of formal and informal female economic ventures, especially the budding market of WeChat-based sales schemas. 
lifestyle. When I expressed to them why it would be difficult for me to become a nun, they responded very quickly and adamantly that the restrictions placed on them as nuns were prohibitive in many ways and that my position as a childless lay woman was actually preferable. This was a topic that we discussed frequently and they cited travel restrictions placed on them by the government, as well as monetary restrictions that prevented them from working and saving money independently and their cultivated but also loathed humility and shyness, as forces that prevented them from seeking out educational opportunities, attending teachings from lamas throughout the Buddhist world, or going into retreat in sacred places. I mention this because I think it is important to note that the nuns did not have a romantic vision of being a nun in opposition to the suffering of married life. They recognize the ways that all life paths have restrictions and that their nun-hood does not shield them from the burden of duty.

Kunchok Palmo is a Dzalung Nunnery nun who wears robes and maintains her vows, but lives at home in a nomadic settlement in Yukdo. The daughter-in-law in their household got fed up with nomadic life and demanded that she and one of the brothers move to the town center. They took a few of the children with them, but left two behind. Feeling that the two grandparents and one son were not equipped to care for the two children, settlement and herds on their own, Kunchok Palmo was called back home from the nunnery. Whenever I visit she has her prayer book propped open on the table, which she references every once in a while as she recites her prayers while adding yak dung to the stove, cooks all the households meals, bathes and entertains the two small children, fetches water, milks the herd, collects and dries the dung, etc. One afternoon during caterpillar fungus season (monastics are prohibited from collecting the caterpillars, because the collection process is considered to kill the animal), Kunchok Palmo and I sit by the fire, clean dirt and debris from the caterpillars, and talk about her life. She would prefer to stay at the nunnery, she says, because there is less work there. This less work is not about simply having more free time, but about having more mental space. Although there is still a lot of work to do to maintain life in the nunnery, it is quieter. The kids don't scream, guests don't come by demanding attention, and the family dramas that occupy a central part of any household are dulled by distance. But the decision is not hers to make. When her parents agree that she can leave again, she will leave. If they decide she must stay, she will stay. Her brother is a monk studying in the monastic college at Dzogchen Monastery in Dzadoe. It would be unthinkable to call him home to care for the family. It is not even open to discussion (dkon mchog dpal mo 2018).

Lay women, like nuns, often talk about marriage and domestic life as a heavy burden on their religious practice. Many women speak longingly about nuns' lives and how much freedom they have to practice.

\section{March 2018}

Tsering Paldron, now 46, married into the Maryontsang family nearby her childhood home as a bride in an arranged marriage at 19. Her mother-in-law had already passed away by the time she arrived. She took on the care of two small children, technically her sisters-in-law, as if they were her own children. She also had a father-in-law, husband, and a large herd of yaks, sheep, and horses to care for. She quickly became pregnant herself and subsequently lost the child. She had difficult births, twice at home and once in a hospital. After some years, her father-in-law decided to move the family back to his hereditary lands a three day's journey away. Although this was a homecoming for her father-in-law, she was moving far from her own family to a completely unfamiliar place. When I ask her about her own religious practice and whether she has the desire to visit monasteries or go on pilgrimage, she says she has so much work to do at home and lacks an education. Her two boys are grown now, both attending college and getting ready to start families of their own, but she doesn't see an end to her domestic duties (tshe ring dpal sgron 2018).

When women gather together for any occasion, complaints about family life are always a popular source of conversation. These might come in the form of raucous jokes about their husbands' small 
and incompetent penises, or more serious discussions about the pains of infertility or complications with IUDs or c-section incisions. Women also compare notes on their husbands and in-laws, finding out which among them have the most difficult home. When women talk about the religious practice they would do if only they had more time, it might be simply rhetorical: a way of simultaneously showcasing domestic dedication and a virtuous aspiration (the same way one talks about future exercise goals or charity donations to be given in the fictional future), but there are also instances where women's labor practices directly impede their ability to attend religious activities.

Palkyi is an extremely tall and buxom woman. She is married for the second time and lives near a monastery where her oldest child lives as a monk. I visit her home one morning and her husband suggests we go circumambulate the monastery and climb the mountain to the retreat complex high up on its hillside. I ask Palkyi to join us, but her husband interrupts to say she cannot leave the house or the fire will go out. Later in the year, Palkyi and I work together in the monastery kitchen during the annual Vajrakilaya festival. She calls me to go with them every time there is a blessing to be received so we can go into the assembly hall together. I ask her each time what empowerment is being given and what blessing we are receiving. She says again and again, "How am I supposed to know? We're all in the kitchen together". But she asks a monk for me each time and reports back his answer. We hide away during our breaks so she can sing nomadic songs for me and complain about her varicose veins.

Despite the frequency of discussions on domestic and child-related labor as impediments to religious practice, women also use aggrandizing language to discuss the relationship between their household and religious labor.

\subsection{Labor as Productive}

$$
14 \text { April } 2018
$$

I bring Namdrol back to the nunnery this morning. On the way we chat about why it seems that so many nuns are performing retreats, while so few monks are doing the same ${ }^{14}$. She says that many lamas, including Lungkar Monastery's own Orgyen Dorje Rinpoche and Khenpo Tsultrim Lodroe, have repeated many times that nuns are better practitioners than monks. They know how to work hard and have a strong motivation for practice, whereas monks like to play and joke around.

The second way women describe their relationship with labor is as a liberative tool. This liberative tool manifests itself in two ways: women have more difficult lives and therefore more easily develop aversion to the material world, and women are trained from a young age to work diligently and have strict discipline, which are necessary traits for a religious life. One of the main catalysts for practice is aversion to the saṃsāric world. In order to turn away from samsāra, a practitioner must realize the inherent suffering of samsāric existence. This realization, of course, can come about through various avenues (seeing the suffering of others, intellectually understanding the impermanence and suffering of the cycle of life and death, etc.), but women claim that their own experiences with suffering make them realize more quickly and more urgently that the world contains boundless suffering. This manifests itself in the pain of leaving home to become a bride in a strange household, of marrying into a large family, of taking on the responsibility of fetching water, lighting the fire, rising first, sleeping last, cooking all meals, cleaning all dishes, kneading the dough, baking the bread, bearing the children, breastfeeding the children, cleaning urine and excrement of those children out of clothing and bedding until they have learned to identify their own needs, performing the milking, collecting fresh dung and spreading it to dry, collecting more water, sometimes from a stream covered in ice more than a

14 There is a strong tradition of retreat practice at Dzalung Nunnery (rdza lung dge dgon). A new retreat complex was built in 2017, and eight nuns were sealed in for their three-year-three-month retreats (lo gsum phyogs gsum). Meanwhile, six other nuns are performing retreats of six years or more in the retreat center on a mountainside adjacent to the nunnery. 
kilometer's walk away, taking care of the aging parents-in-law, and satisfying the needs of all male brothers of the household, all without the ability to read, write, drive a car, open a bank account, or leave the confines of the home without permission or a chaperone. When discussing with women whether or not their lives are more difficult than those of their male relatives, I am almost always met with laughter. It is laughable to even question out-loud whose lives are more difficult.

\section{December 2016}

Karma Dorje is a monk and teacher of a prominent lama. During dinner one evening, he asks me jokingly if I think I could marry a nomadic man and become a bride. I tell him no, that I am amazed by how much work women do and how little mobility they have. I tell him I admire the women, but I wouldn't be able to do it myself. He laughs and agrees that brides in this region are really thought of as female servants (gyog mo). He lived for many years in India and knows that American women do not have the same status in the household, so he asks me if it bothers me to see women in this position. I tell him I do feel angry sometimes when I see pregnant women breastfeeding their older children and then performing all the household duties (including carrying very heavy materials) while their husbands smoke cigarettes, watch TV, and make demands. He laughs but says seriously that it is healthy for women to work hard during their pregnancies and that hard work through the end of pregnancy will ensure an easy labor and a healthy child. I ask him what medical evidence there is of this and he shrugs. I tell him the person who decided that carrying 30 kilos of water on your back at eight months pregnant was healthy for the mother and child was surely a lazy husband trying to get out of helping his wife. He laughs and says I would make a bad bride (karma rdo rje 2016).

Not only are women more experienced in the painful nature of saṃsāra, but their lives of labor, cultivated from a very early age, prepare them mentally and physically for a life of religious labor. Buddhist liberation is often framed as a difficult, tedious, and vicious process, one that requires extreme dedication, devotion, faith, and perseverance. Liberation through Vajrayāna is not for the faint of heart, and women have cultivated that knowledge in their lived experiences from a very young age.

\section{Conclusions: Labor Is Not Pure}

It is tempting to imagine that because labor is transformative, it is also inherently good for women, that these toils are romantic and value-positive. Far from shifting the paradigm, we would just be swapping in variables - the philosophic and literate avenues of Buddhist study are less pure Buddhism than the bodily labor of the masses. However, this is not what I hope to achieve. First of all, the women of Bongwa Mayma maintain an ambivalent attitude toward the productive power of labor. Domestic and child labor can be simultaneously a distraction from and a catalyst toward religious practice. Labor of the body within the home can build the necessary skills of perseverance, patience, and endurance needed for a strong spiritual practice. On the other hand, the work women perform in the household can hold them back from having the time, energy, and resources needed to devote to their Preliminary Practices. The very physically demanding entry into religious practice presented in the Preliminary Practices is a form of labor: a productive and inevitable aspect of religious life that produces real results. Something happens to women when they perform 100,000 prostrations. The callouses and wounds and aching joints are an external manifestation of an internal process of submission. But submission is not inactive. Women take time out of their labor-filled days to turn their minds and bodies toward the object of their Refuge. They do so not out of convenience, but out of devotion and faith for a lama, for the teachings, and for the promise that this labor will change them.

The relationship that I seek to describe between women, their bodies, and religious realization in a Buddhist context is complicated by the Buddhist understanding of the self. Buddhist women in Bongma Mayma understand the self as an inherently empty misperception of complete interdependence. Holding on to a concept of self (bdag 'dzin) is one of the grave offences of Buddhism. So if we were to assume that agency and opposition to systems of authority and power, or even submission to or creation 
of norms, rely upon an independent, individual, and unchanging self, we get nowhere. The self, according to Buddhist women, is co-arisen. It does not exist in any essential form. It cannot act outside of anything. There is no outside. There is no self. For women in Bongwa Mayma, questions about how agency operates in relation to an independent, desire-filled self are not relevant, by which I mean they are not possible to ask. It is not, like in Mahmood's work, that they express their agency in the form of conceding and adhering to religious norms. For the women of Bongwa Mayma, the very aim of their practice is to dissolve the self, not into a collective or social structure of piety (Mahmood 2011), but into emptiness itself. I do not make the argument that the foundational Buddhist principle of no-self (bdag med) forestalls the ability of Buddhist women to exert agency. Instead, I utilize the category of labor to think through agency as something other than an exertion of self. Labor is interesting because it is both productive of and producing of transformation. Labor itself is an act of transformation, one that simultaneously produces transformation in the object and agent of labor. This is confluent with the Buddhist principle that transformation is both inevitable (as all phenomena are impermanent) and necessary for realization. In this model, neither labor nor transformation are reliant upon a free-willed, independent, and permanent self. Labor can be performed; effort can be exerted; transformation can and must take place. These processes have an agent, in the same way an active verb is performed by a doer, even if that agent does not have, nor maintain the view that they have, a permanent self.

The transformative religious labor of prostrations, in this context, is not practitioners' first encounter with Buddhist teachings or rituals, but it is likely the beginning step toward a serious and prolonged commitment to the Buddhist path. It is not possible to perform 100,000 prostrations without an enduring commitment. The torn muscles, calloused knees, and aching joints are themselves multifold; external manifestations of inner dedication and barriers that, once overcome, open up the mind and body to new experiences of realization. The end of the prostration accumulation portion of one's Preliminary Practices can be a bit anti-climactic. After days or months of work, practitioners prostrate for the last time, not really knowing how to stop. Their muscles trained to always move in the same way, prostration after prostration, hour after hour, day after day. The body has been broken down, the ego demolished. While performing prostrations at Bodhgaya, Bongwa Mayma nun, Changchub Sangmo, describes what happens when the pain of prostrations is transformed: "You feel bliss at the expansiveness of your mind. Your body is light and limber and your mind empty. The effort becomes effortless. You forget your aching limbs" (byang chub bzang mo 2018). This ability to change mundane suffering into profound understanding is not exclusive to women. But as a demographic, Tibetan women of rural Qinghai are more likely, and at a younger age, to have experienced suffering in a visceral and consistent way. Through labor-intense, brutal, painstaking labor-the women of Bongwa Mayma cultivate the skill of transforming suffering into realization. Opportunities to turn saṃāric pain into enlightened bliss are plentiful for the women of Bongwa Mayme, but prostrations prove especially good practice for subsequent stages of the path: practice turning bloody knees, calloused palms, and aching limbs into unadulterated bliss.

Funding: Funding for this research was provided by the Mershon Center for International Security Studies, the China and Inner Asia Council of the Association for Asian Studies, Fulbright IIE, The Robert H N Ho Foundation and the Fulbright-Hays Doctoral Dissertation Research Abroad program.

Acknowledgments: A version of this paper was presented at the University of Oxford, Oriental Institute, Tibetan Graduate Studies Seminar. Thank you to those seminar organizers and participants for their valuable feedback and to Namkha Drongpa for his generous suggestions.

Conflicts of Interest: The author declares no conflict of interest. 


\section{References}

\section{Primary Literary Sources}

lho bstan 'dzin nyi ma, ed. 2008. Oral Instructions on Amitabha Pureland Preliminary Practices. [16 sound files]. Obtained April 2018.

lho bstan 'dzin nyi ma, ed. 2019a. phyag chen Inga ldan gyi nyams len snying btus nges don lam bzang. 'drong ma smad ma: lho lung dkar dgon gangs bod chos rig dar spel dpe tshogs.

lho bstan 'dzin nyi ma, ed. 2019b. Oral Instructions on Fivefold Mahamudra Preliminary Practices. Recordings made by the author during live teachings, December 9-15.

lho rje drung nus ldan rdo rje. 2008. zab chos bde chen zhing sgrub kyi sngon 'gro'i khrid yig lam mchog padma'i thems skas [Instructional Text for the Preliminary Practices of the Profound Teachings of Amitabha's Pureland Sadhana: Steps on the Supreme Lotus Path]. Edited by lho bstan 'dzin nyi ma. lho lung dkar dgon: 'brong smad lho lung dkar dgon shes rig nyams gso tshogs khang.

rdza dpal sprul. 19th century. rdzogs pa chen po klong chen snying tig gi sngon 'gro'i khrid yig kun bzang bla ma'i zhal lung [Words of My Perfect Teacher]. smin grol gling: dga' dpon blo bzang don grub. TBRC W22270.

\section{Primary Recorded Interviews}

a ne. 2018. Oral History Interview with Aney. March 29.

byang chub bzang mo. 2018. Changchub Sangmo Interview. September 25.

dkon mchog dpal mo. 2018. Interview with Kunchok Palmo. June 6.

karma rdo rje. 2016. Karma Dorje Interview. December 31.

pa sangs. 2018. Pasang Oral History. April 5.

tshe ring dpal sgron. 2018. Oral History Interview with Tsering Paldron. March 20.

\section{Secondary Literature}

Adhe, Ama. 1997. Ama Adhe, the Voice That Remembers: The Heroic Story of a Woman's Fight to Free Tibet. Somerville: Wisdom Publications.

Allione, Tsultrim. 1984. Women of Wisdom. London: Routledge \& Kegan Paul plc.

Arai, Paula. 2011. Bringing Zen Home: The Healing Heart of Japanese Women's Rituals. Honolulu: University of Hawaii Press.

Aziz, Barbara Nimri. 1987. Moving towards a Sociology of Tibet. The Tibet Journal 12: $72-86$.

Aziz, Barbara Nimri. 1988. Women in Tibetan Society and Tibetology. In Tibetan Studies: Proceedings of the 4th Seminar of the International Association for Tibetan Studies, Munich. Munich: Kommission fur Zentralasiatische Studien, Bayerische Akademie der Wissenschaften.

Balkwill, Stephanie. 2018. Why Does a Woman Need to Become a Man in Order to Become a Buddha?: Past Investigations, New Leads. Religion Compass 12: e12270. [CrossRef]

Benston, Margaret. 1969. The Political Economy of Women's Liberation. Monthly Review 21: 13-27. [CrossRef]

Bessenger, Suzanne. 2017. 'I Am a God, I Am a God, I Am Definitely a God': Deity Emanation and the Legitimation of Sönam Peldren. Revue d'Etudes Tibétaines 38: 84-103.

Bianchi, Ester. 2019. Transmitting the Precepts in Conformity with the Dharma: Restoration, Adaptation, and Standardization of Ordination Procedures. In Buddhism after Mao: Negotiations, Continuities, and Reinventions. Edited by Ji Zhe, Gareth Fisher and Andre Laliberte. Honolulu: University of Hawaii Press, pp. 152-70.

Blackstone, Kathryn R. 1998. Women in the Footsteps of the Buddha: Struggle for Liberation in the Therigatha. Delhi: Motilal Banarsidass Publishers.

Boesi, Alessandro. 2003. 'dbyar Rtswa Dgun 'bu Is a Marvellous Thing' Some Notes on the Concept of Ophiocordyceps Sinensis among Tibetan People and Its Significance in Tibetan Medicine. The Tibet Journal 28: 29-42.

Cabezon, Jose Ignacio, ed. 1992. Buddhism, Sexuality, and Gender. Delhi: Sri Satguru Publications.

Craig, Sienna R. 2009. Pregnancy and Childbirth in Tibet: Knowledge, Perspectives, and Practices. In Childbirth Across Cultures: Ideas and Practices of Pregnancy, Childbirth and the Postpartum. Edited by Helaine Selin. Berlin: Springer, pp. 145-60. 
Diemberger, Hildegard. 2007. When a Woman Becomes a Religious Dynasty: The Samding Dorje Phagmo of Tibet. New York: Columbia University Press.

Faure, Bernard. 1998. The Red Thread: Buddhist Approaches to Sexuality. Princeton: Princeton University Press. Faure, Bernard. 2003. The Power of Denial: Buddhism, Purity and Gender. Princeton: Princeton University Press. Fuss, Diana. 1989. Essentially Speaking: Feminism, Nature and Difference. New York: Routledge.

Gayley, Holly. 2017. Love Letters from Golok: A Tantric Couple in Modern Tibet. New York: Columbia University Press. Grosss, Elizabeth. 1985. Criticism, Feminism and the Institution: An Interview with Gayati Chakravorty Spivak on August 17, 1984. Thesis Eleven 10-11: 175-87.

Grosz, Elizabeth. 1995. Sexual Difference and the Problem of Essentialism. In Space, Time, and Perversion. New York: Routledge.

Gruschke, Andreas. 2008. Nomads without Pastures? Globalization, Regionalization, and Livelihood Security of Nomads and Former Nomads in Northern Khams. Journal of the International Association of Tibetan Studies 4: $1-40$.

Gutschow, Kim. 2001. The Women Who Refuse to Be Exchanged: Nuns in Zangskar, Northwest India. In Celibacy, Culture, and Society: The Anthropology of Sexual Abstinence. Edited by Elisa J. Sobo and Sandra Bell. Madison: University of Wisconsin Press, pp. 47-63.

Gutschow, Kim. 2004. Being a Buddhist Nun: The Struggle for Enlightenment in the Himalayas. Cambridge: Harvard University Press.

Gyatso, Janet, and Hanna Havnevik, eds. 2005. Women in Tibet. New York: Columbia University Press.

Havnevik, Hanna. 1990. Tibetan Buddhist Nuns: History, Cultural Norms and Social Reality. Oslo: Norwegian University Press.

Havnevik, Hanna. 1999. The Life of Jetsun Lochen Rinpoche (1865-1951) as Told in Her Autobiography. Ph.D. dissertation, University of Oslo, Oslo, Norway.

Heirman, Ann. 2001. Chinese Nuns and Their Ordination in Fifth Century China. Journal of the International Association of Buddhist Studies 24: 275-304.

Heirman, Ann. 2011. Buddhist Nuns: Between Past and Present. Numen 58: 603-31. [CrossRef]

Henrion-Dourcy, Isabelle. 2005. Women in the Performing Arts: Portraits of Six Contemporary Singers. In Women in Tibet: Past and Present. New York: Columbia University Press.

Hooks, Bell. 1981. Ain't I a Woman: Black Women and Feminism. Boston: South End Press.

Hooks, Bell. 2000. Where We Stand: Class Matters. New York: Routledge.

Horner, I. B. 1930. Women Under Primitve Buddhism: Laywomen and Almswomen, 2nd ed. Delhi: Motilal Banarsidass Publishers.

Jacoby, Sarah H. 2014. Love and Liberation: Autobiographical Writings of the Tibetan Buddhist Visionary Sera Khandro. New York: Columbia University Press.

Keyes, Charles F. 1984. Mother or Mistress but Never a Monk: Buddhist Notions of Female Gender in Rural Thailand. American Ethnologist 11: 223-41. [CrossRef]

Kukuczka, Anne. 2016. Smartphones, Weixin and Beautiful Bodies: The Role of Mobile Technologies for Crafting Desired Selves in Lhasa. Revue d'Etudes Tibétaines 37: 178-206.

Langenberg, Amy. 2017. Birth in Buddhism: The Suffering Fetus and Female Freedom. New York: Routledge.

Law, Bimala Churn. 1927. Women in Buddhist Literature. Ceylon: W.E. Bastian \& Co.

Mahmood, Saba. 2011. Politics of Piety: The Islamic Revival and the Feminist Subject. Princeton: Princeton University Press.

Makley, Charlene. 1997. The Meaning of Liberation: Representations of Tibetan Women. The Tibet Journal 22: 4-29.

Makley, Charlene. 1999. Gendered Practices and the Inner Sanctum: The Reconstruction of Tibetan Sacred Space in 'China's Tibet. In Sacred Spaces and Powerful Places in Tibetan Culture. Edited by Toni Huber. Dharamsala: Library of Tibetan Works and Archives, pp. 343-66.

Makley, Charlene. 2002. Sexuality and Identity in Post-Mao A Mdo. In Amdo Tibetans in Transition: Society and Culture in the Post-Mao Era. Edited by Toni Huber. Leiden: Brill.

Makley, Charlene. 2007. The Violence of Liberation: Gender and Tibetan Buddhist Revival in Post-Mao China. Berkeley: University of California Press.

Martin, Dan. 2005. The Woman Illusion? Research into the Lives of Spiritually Accomplished Women Leaders of the 11th and 12th Centuries. In Women in Tibet. Edited by Janet Gyatso and Hanna Havnevik. New York: Columbia University Press, pp. 49-82. 
McDougal, Elizabeth. 2016. Coming Down the Mountain: Transformations of Contemplative Culture in Eastern Tibet. Sydney: University of Sydney.

Melnick, Alison. 2020. Beyond the Recovery of Women: The Evolving Study of Gender in Tibetan Buddhism. Religion Compass 14: e12287. [CrossRef]

Mills, Martin A. 2000. Vajra Brother, Vajra Sister: Renunciation, Individualism and the Household in Tibetan Buddhist Monasticism. Journal of the Royal Anthropological Institute 6: 17-34. [CrossRef]

Namgyal Lhamo Taklha. 2004. Women of Tibet. Dharamsala: Songtsen Library.

Paul, Robert A. 1989. The Sherpas of Nepal in the Tibetan Cultural Context-The Tibetan Symbolic World: A Psychoanalytic Exploration. Delhi: Motilal Banarsidass Publishers.

Schaeffer, Kurtis R. 2004. Himalayan Hermitess: The Life of a Tibetan Buddhist Nun. Oxford: Oxford University Press. Shaw, Miranda. 1995. Passionate Enlightenment: Women in Tantric Buddhism. Princeton: Princeton University Press. Simpson, Audra. 2014. Mohawk Interruptus: Political Life Across the Borders of Settler States. Durham: Duke University Press.

Spivak, Gayatri. 1993. In a Word: Interview. In Outside in the Teaching Machine. New York and London: Routledge. Tsomo, Karma Lekshe, ed. 1988. Sakyadhita: Daughters of the Buddha. Delhi: Sri Satguru Publications.

Vogel, Lise. 1995. Woman Questions: Essays for a Materialist Feminism. Hove: Psychology Press.

Winkler, Daniel. 2009. Caterpillar Fungus (Ophiocordyceps Sinensis) Production and Sustainability on the Tibetan Plateau and in the Himalayas. Asian Medicine 5: 291-316. [CrossRef]

Publisher's Note: MDPI stays neutral with regard to jurisdictional claims in published maps and institutional affiliations. 